\title{
Penggunaan Metode Simulated Annealing untuk Optimasi Penempatan Posisi Access Point pada Jaringan WI-FI
}

\author{
Ganang Eko Noviardianto ${ }^{1}$, Muhammad Novel $^{1}$, Mercurius Broto Legowo $^{1}$ \\ ${ }^{1}$ Program Studi Teknik Informatika, Fakultas Teknologi Informasi, Perbanas Institute-Jakarta, \\ Jl.Perbanas, Karet Kuningan, Setiabudi, Jakarta Selatan 12940
}

Penulis untuk Korespondensi/E-mail: ganangeko20@gmail.com

\begin{abstract}
Abstrak - Tujuan dari penelitian ini adalah untuk menempatkan titik akses pada jaringan Wi-Fi. Dengan demikian, kekuatan sinyal yang diterima dari pemancar ke penerima adalah optimal. Masalah muncul ketika menempatkan titik akses untuk mempengaruhi nilai kekuatan sinyal. Selanjutnya, nilai ini akan digunakan untuk menentukan area jangkauan (jangkauan sinyal) dari pemancar (access point). Penelitian ini adalah studi kasus di Kampus Institut Perbanas di mana pengukuran kekuatan sinyal dari titik akses terhadap penerima di unit 2 dan unit 6 dari Perbanas Institute diukur menggunakan aplikasi inSSIDer. Studi kasus ini menghasilkan nilai Indikasi Kekuatan Sinyal yang Diterima (RSSI) dari pemancar ke penerima. Metode Simulated Annealing diterapkan dalam penelitian ini, dengan alasan untuk optimasi generik. Berdasarkan probabilitas dan mekanika statistik, algoritma ini dapat digunakan untuk menemukan pendekatan pada solusi optimal untuk suatu masalah. Hasil penelitian menunjukkan bahwa setelah dilakukan optimisasi menggunakan metode Simulated Annealing prosentase koverage area sebesar 98.66 \% dan, diperoleh kenaikan persentase koverage area sebesar 87.15\%. Dengan demikian, penelitian ini akan memberikan kontribusi untuk memodelkan penempatan posis titik akses dan kekuatan sinyal pada jaringan Wi-Fi yang diperoleh di Unit 2 dan Unit 6 Kampus Institut Perbanas
\end{abstract}

Abstract - The purpose of this study is to place access points on Wi-Fi networks. Thus, the signal strength received from the transmitter to the receiver is optimal. Problems arise when placing access points to influence the signal strength value. Furthermore, this value will be used to determine the koverage area (signal koverage) of a transmitter (access point). This research is a case study at the Perbanas Institute Campus where measurements of the signal strength of the access point towards recipients in unit 2 and unit 6 of Perbanas Institute were measured using the inSSIDer application. This case study produced a Received Signal Strength Indication (RSSI) value from a transmitter to the receiver. The Simulated Annealing method applied in this study, with reasons for generic optimization. Based on probability and statistical mechanics, this algorithm can be used to find an approach to the optimum solution to a problem. The results showed that after optimization using the Simulated Annealing method the percentage of koverage area was $98.66 \%$. And, the percentage of the koverage area was increased by $87.15 \%$. Thus, this study will contribute to modeling the placement of access points and signal strength in Wi-Fi networks obtained in Units 2 and 6 of the Perbanas Institute Campus.

Keywords - Koverage Area, RSSI, Simulated Annealing, Propagation, Wi-Fi

\section{PENDAHULUAN}

$\mathrm{P}$ enempatan access point secara optimal merupakan salah satu permasalahan di bidang infrastruktur jaringan komputer, dikarenakan untuk menempatkan titik akses (access point) secara optimal pada jaringan Wi-Fi diperlukan pertimbangan dan analisa teoritis sebelum diimplementasikan [1]. Terdapat beberapa cara praktis yang dapat dilakukan untuk menempatkan access point, yakni menempatkan access point di tengah-tengah ruangan atau lokasi, namun terkadang hal ini tidak dapat dilakukan karena dalam perencanaan pengembangan jaringan Wi-Fi tidak hanya sekedar memasang infrastruktur perangkat access point, tetapi juga harus memperhatikan beragam faktor antara lain kekuatan daya pancar sinyal access point, desain dan infrastruktur ruangan, sebaran pengguna access point yang berkelompok, terjadinya interferensi gelombang 
radio, hambatan sinyal seperti frekuensi radio, dan penghalang yang dapat menimbulkan gangguan terhadap penerimaan sinyal dari access point (transmitter) terhadap perangkat penerima (receiver). Posisi access point sangat berpengaruh terhadap koverage area untuk penerima pada sebuah jaringan Wi-Fi. Semakin optimal penempatan posisi access point, semakin optimal juga koverage area untuk penerima.

Penempatan access point cara manual akan membutuhkan tenaga yang lebih untuk melakukan survei pengukuran dilapangan, waktu yang lama dan biaya yang tidak murah [2]. Untuk itu dibutuhkan penanganan dan mekanisme yang baik dalam meminimalisir tenaga, biaya dan waktu seorang perencana jaringan Wi-Fi dalam menempatkan access point pada tempat yang optimal sehingga cakupan area yang dihasilkan lebih optimal serta dapat menentukan jumlah access point yang ideal untuk suatu lokasi dengan berbagai ukuran yang ada yang dapat ditentukan melalui perhitungan tanpa melakukan survei lapangan yang aktual. Penempatan access point pada jaringan Wi-fi yang tepat sangat diperlukan untuk mengoptimalkan kekuatan sinyal yang sering diterima dari transmitter terhadap receiver. Parameter yang paling mempengeruhi dalam menentukan performa access point adalah nilai kekuatan sinyal, karena nilai inilah yang akan digunakan untuk menentukan koverage area cakupan sinyal) dari sebuah transmitter. Penelitian ini akan dilakukan pengukuran terhadap kekuatan sinyal access point terhadap penerima dikampus Perbanas Institute, yang akan diukur menggunakan aplikasi insider dan menghasilkan nilai RSSI (Received Signal Strength Indication) dari sebuah transmitter terhadap receiver.

RSSI menunjukkan intensitas sinyal yang diterima dan dapat diukur dengan mempertimbangkan sinyal yang dikirimkan dari dasar ke simpul sensor (uplink) atau dari sensor simpul ke pangkalan (downlink) [3]. Dalam melakukan pengukuran juga menggunakan propagasi Line Of Sight (LOS) dan propagasi Non Line Os Sight (NLOS). Definisi paling sederhana dari Line of Sight (LOS), adalah jalan lurus antara dua titik tetap dalam ruang dua atau tiga dimensi saat tidak terhalang oleh cakrawala [4]. Di sisi lain, nonline-of-sight (NLOS) adalah jalur tidak langsung dari satu titik ke titik lain dalam ruang dua atau tiga dimensi. Data yang diperolan dari hasil pengukuran dilapangan digunakan untuk melakukan pemodelan penempatan access point menggunakan metode simulated annealing. Simulated annealing adalah algoritma pencarian lokal (meta-heuristic) yang mampu mendapatkan hasil secara optimal dari suatu area [5]. Kemudahan implementasi, sifat konvergensi dan penggunaannya menjadikan metode ini telah menjadi teknik yang populer dalam dua dekade terakhir. Simulated annealing merupakan metode searching yang memanfaatkan teori probabilitas untuk mencari global minimum dari suatu permasalahan optimasi. Simulated annealing umumnya digunakan untuk variabel yang bersifat categorical. Target dari metode ini adalah menemukan solusi bagus yang bisa diterima, bukan untuk mencari solusi yang terbaik. Nama annealing berasal dari keilmuan metallurgy, di mana proses tersebut akan berusaha mencari suatu posisi suhu tertentu yang optimal untuk mengurangi kerusakan dan menambah ukuran kristal di dalam suatu material.

Beberapa peneliti sebelumnya telah mmelakukan penelitian terkait hal ini. Penelitian mengenai optimasi access point jaringan wifi memperlihatkan cara untuk menentukan koverage area maksimum dengan metode Monte Carlo berdasarkan fungsi jarak dari hasil pengukuran di lapangan. Berdasarkan hasil pengukuran dapat diketahui bahwa level daya terima berbanding terbalik dengan jarak antara pemancar (Tx) dan penerima (Rx), semakin jauh jarak antara pemancar (Tx) dan penerima (Rx) maka level daya terima semakin kecil [6]. Penelitian terkait suatu cara untuk menentukan koverage area maksimum dengan algoritma genetika melalui perhitungan parameter yang dicari untuk menentukan fungsi fitness dari algoritma genetika berdasarkan fungsi jarak dari hasil pengukuran di lapangan. Berdasarkan cara tersebut dapat disimpulkan bahwa level daya terima berbanding terbalik dengan jarak antara pemancar (Tx) dengan penerima (Rx); semakin jauh jarak antar pemancar $(\mathrm{Tx})$ dan penerima $(\mathrm{Rx})$ maka level daya terima semakin kecil [7]. Penempatan optimal posisi access point berdasarkan sebuah algoritma baru dapat menentukan keberhasilan [8]. Penggunaan metode Simulated Annealing untuk melakukan optimasi distribusi barang berdasarkan rute dan daya tampung [9] untuk membentuk algoritma simulated annealing untuk lokalisasi WiFi dengan menggunakan Google Indoor Map. Maka tentunya penelitian sebelumnya ini berbeda dengan yang dilakukan dalam penelitian ini baik dari tujuan atau pendekatan yang dilakukan.

Pada penelitian ini, bertujuan untuk melakukan pengukuran sinyal pada access point lingkup unit 2 dan 6 Kampus Perbaas Institute - Jakarta dan mengoptimiasai arsitektur jaringan baru yang 
disertai dengan display contour jaringan yang dapat mencangkup seluruh area gedung unit 2 dan 6 Perbanas Institute, serta memberikan usulan optimasi terhadap letak pemasangan access point untuk menghindari adanya ruangan atau tempat yang tidak terjangkau sinyal access point dengan baik dan memperkecil gangguan sinyal dari beberapa faktor seperti tembok beton, lantai, aktifitas manusia dan pintu.

Harapannya, penelitian ini memberikan kontribusi untuk model penempatan access point dan kekuatan sinyal yang diperoleh di Unit 2 dan Unit 6 Kampus Institut Perbanas-Jakarta.

\section{METODE}

\section{Desain, tempat dan waktu}

Penelitian ini membuat desain model penempatan titik akses dan kekuatan sinyal yang diperoleh area kampus Institut Perbanas. Penelitian ini dilaksanakan dilingkungan unit 2 dan 6 Perbanas Institute Jakarta, dimana untuk propagasi LOS dilaksanakan di ruang dosen dan untuk propagasi NILOS dilakasanakan dilobi unit 6 lantai 1 . Sedangkan waktu pelaksanaan adalah pada tanggal 11 Agustus 2017 - 25 Mei 2018. Denah penelitiain memiliki luas $226.80 \mathrm{~m}^{2}$ yang didalamnya terdapat 20 meja dengan ketinggian $0.75 \mathrm{~m}$, sedangkan tinggi ruas meja $1.2 \mathrm{~m}$. Sedangkan lobi memuat ruang terbuka dan tangga serta lift untuk menuju kelantai 2.

\section{Jumlah dan cara pengambilan subjek}

Dalam penelitian ini dibutuhkan alat dan bahan sehingga penelitian berjalan dengan lancar. Alat yang digunakan adalah Access Point dan Netbook/Handphone. Access Point adalah alat yang berfungsi sebagai transmitter yang memancarkan sinyal gelombang radio. Sedangkan, Netbook/Handphone berfungsi sebagai receiver yang menerima pancaran sinyal gelombang radio dari sebuah atau beberapa access point. Bahan yang digunakan dalam penelitian berupa InSSIDER yang berfungsi sebagai software aplikasi gratis yang digunakan untuk scanning jaringan Wi-Fi dengan parameter utama SSID dan dapat melacak kekuatan sinyal dari waktu ke waktu serta menentukan pengaturan keamanan, yang dipasang pada Netbook ASUS Eee PC dengan Sistem Operasi Windows 7. Disamping itu, Kabel UTP yang digunakan untuk menghubungkan antara repeater dan access point, serta Meteran yang digunakan untuk mengukur ketinggian access point yang terpasang dan ketinggian receiver.

\section{Jenis dan cara pegumpulan data}

Pertama, melakukan perencanaan penelitian yang membahas mengenai data yang akan diambil pada saat penelitian meliputi denah, tinggi access point, koordinat, jarak, RSSI dan propagasi. Kedua, Menentukan koordinat posisi Access Point dan posisi receiver pada propagasi LOS (Line Of Sight) dan NLOS (Non Line Of Sight), untuk posisi receiver terdapat 43 titik koordinat pada propagasi LOS, dan posisi receiver terdapat 65 titik koordinat propagasi NLOS. Ketiga, Aplikasi inSSIDER yang telah dijalankan akan melaporkan data terhadap nilai RSSI yang diterima oleh receiver. Akhirnya, maka pengumpulan data selesai.

\section{Pengolahan dan Analisis data}

Pemodelan sistem yang akan dibangun pada penelitian ini adalah menggunakan bahasa pemrograman Java. Pemodelan yang dibuat dalam optimisasi penempatan posisi access point menggunakan ruang 2 (dua) dimensi sedangkan metode yang digunakan adalah simulated annealing. Penghitungan terhadap parameter-parameter yang dicari yaitu menentukan fungsi evaluasi atau fungsi objektif dari simulated annealing yang dihasilkan dari fungsi jarak, penghalang, ketinggian transmitter, pengguna, tipe dan merk access point dari hasil pengukuran di lapangan dan melakukan pengujian terhadap 2 (dua) buah perangkat access point yang diletakkan dalam ruang 2 (dua) dimensidengan sistem propagasi Line Of Sight (LOS) dan Non Line Of Sight (NLOS).

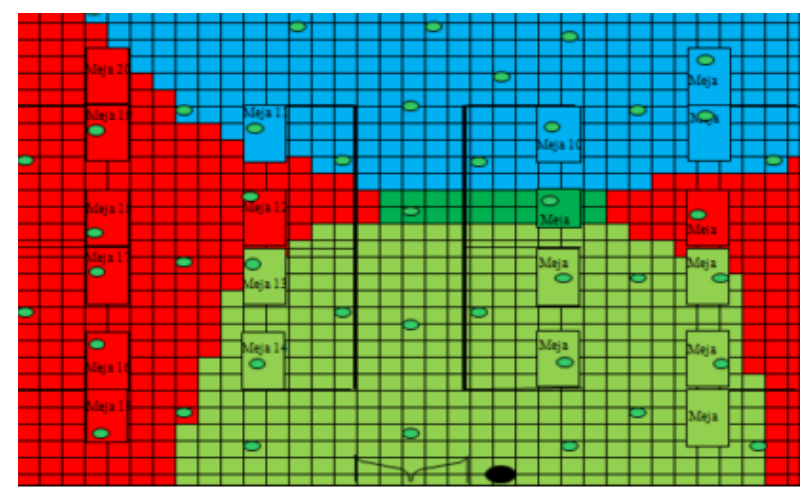

Gambar 1. Sample area ter-kover koordinat access point $(22,28)$ dan $(22,3)$ propagasi LOS dan ketinggian access point $120 \mathrm{~cm}$

\section{Pemodelan Sistem Berdasarkan Metode Simulated annealing}

Pada pemodelan menggunakan simulated annealing, akan dikembangkan sebuah model implementasi 
metode simulated annealing untuk penempatan 2 (dua) posisi access point menggunakan interferensi. Ada beberapa hal yang harus dirancang dalam menerapkan metode simulated annealing yaitu fungsi objektif (cost function), mekanisme inisialisasi solusi awal dan pembuatan solusi baru, skema pendinginan atau (cooling schedule) dan penetapan batasan terhadap output yang dikehendaki. Tiap hal tersebut akan diuraikan pada bagian - bagian berikut ini:

\section{Fungsi Objektif.}

Fungsi objektif yang dicari adalah nilai area terkovernya paling besar berdasarkan atas nilai jarak antara transmitter dan receiver diantara sejumlah posisi access point yang telah diinisialisasi secara acak. Pada perhitungan nilai objektif, setelah diperoleh solusi sementara, dilakukan perhitungan jarak baru antara transmitter dan receiver, kemudian diperoleh range baru, selanjutnya dihitung nilai RSSI baru dari receiver, dan hasil akhir dilakukan perhitungan nilai area terkover.

\section{Inisialisasi Awal dan Mekanisme Pembuatan Solusi Baru}

Pada penelitian ini, solusi awal untuk formasi penempatan access point diinisialisasi secara acak dengan cara membagi access point secara acak kedalam koordinat - koordinat yang terdapat pada area penelitian, koordinat ini didapat berdasarkan jumlah ubin dalam ruang penelitian dimana koordinat panjang (koordinat $\mathrm{x}$ ) dan koordinat lebar (koordinat y) dan setiap access point akan mengalokasikan kepada receiver nilai RSSI yang baru pada koordinat tertentu yang telah ditetapkan sehingga diperoleh perubahan jarak antara acess point dan receiver, kemudian akan dihitung nilai range yang baru untuk menghasilkan nilai area terkover optimal. Mekanisme yang digunakan untuk membangkitkan solusi baru adalah pilih access point secara acak terhadap koordinat sebagai tempat posisi access point yang baru, yang bukan merupakan koordinat yang ditempati sebelumnya, kemudian setiap access point akan mengalokasikan kepada receiver dengan nilai RSSI yang baru sesuai dengan perubahan jarak.

\section{Skema Pendinginan}

Sebelum proses dilakukan, harus ditetapkan terlebih dahulu skema pendinginan yang akan digunakan. Pada prinsipnya, semakin lambat proses annealing berlangsung, maka semakin besar peluangnya untuk menghasilkan solusi yang lebih baik, karena jumlah solusi yang dapat dievaluasi semakin banyak atau ruang pencarian yang dapat dijelajahi semakin luas. Ada tiga cara yang ditempuh untuk memperlambat laju proses annealing, yaitu: dengan memperbesar nilai temperatur awal, atau memperkecil temperatur akhir, memperbesar faktor penurunan temperatur dan memperbesar jumlah iterasi dalam tiap nilai dalam tiap nilai temperatur.

\section{Proses Iterasi}

Proses Iterasi dilakukan untuk mencari nilai nilai area terkover paling optimal dimana proses iterasinya dilakukan dengan metode pencarian acak tanpa nilai target, pencarian dilakukan hingga diperoleh nilai tertinggi, karena tanpa nilai target maka solusi saat ini lu dibandingkan dengan nilai sebelumnya untuk sela menunjukkan tingkat akurasi dari nilai solusi.

Berdasarkan uraian di atas, akan dikembangkan sebuah pemodelan menggunakan metode simulated annealing pada penempatan posisi access point seperti ditunjukkan pada Gambar 2.

Bagaimana cara bekerjanya metode simulated annealing untuk menempatkan posisi access point dalam wifi di unit 6 dan unit 2 Perbanas Institute. Tahap awal membangkitkan acak posisi awal kedua titik access point (POa) dan (POb). Setelah itu mulailah menentukan nilai RSSI baru dan menghitung area terkover $(\mathrm{COa})$ dan $(\mathrm{COb})$ serta menghitung fungsi energi keduaa access point. Selanjutnya, seluruh area terkover akan tersaring dan apabila area terkover lolos maka akan masuk ke tahap optimalisasi posisi, sedangkan apabila tidak lolos maka akan kembali membangkitkan kedua posisi koordinat access point secara acak terhadap solusi sementara. Untuk optimalisasi posisi yang sudah berhasil akan melakukan perhitungan fungsi energi dan melakukan penetapan solusi sementara mulai dari posisi optimal sampai area terkover apabila berhasil. Selanjutnya, menentukan bilangan random apabila gagal maka akan distop dan akan dilakukannya penurunan temperatur pada kedua titik access point dan kembali pada tahap baangkitnya titik koordinat kedua access point. 


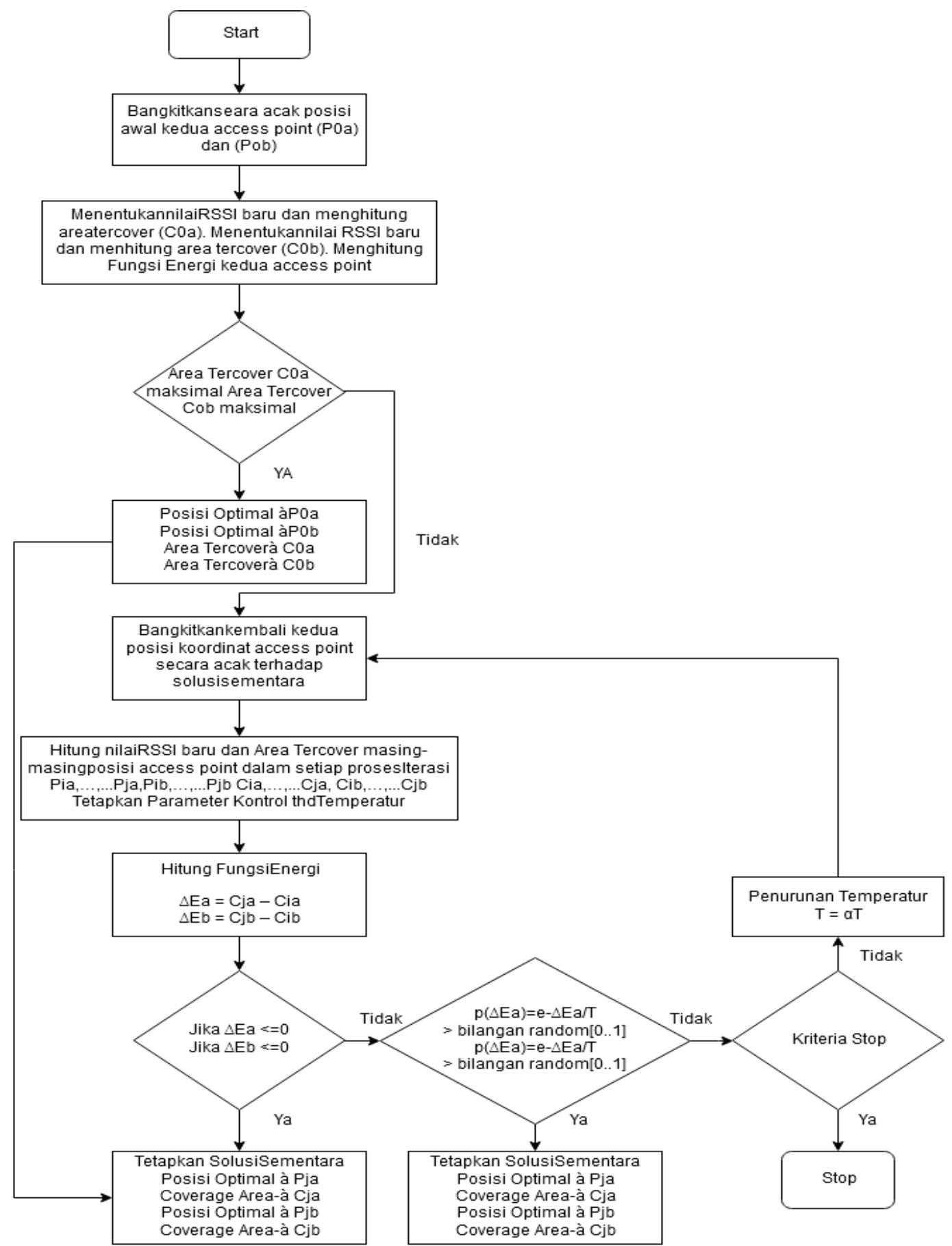

Gambar 2. Flowchart Model penempatan posisi Access Point dengan interferensi menggunakan Simulated Annealing 


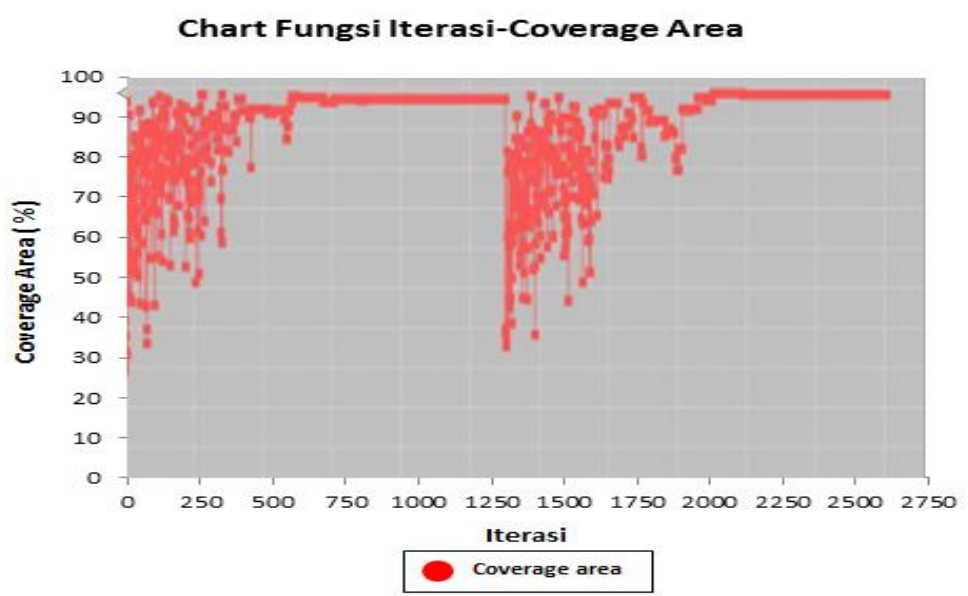

Gambar 3. Sample Grafik Iterasi Koverage Area Hasil Pemodelan Tinggi AP $50 \mathrm{~cm}$ Propagasi LOS

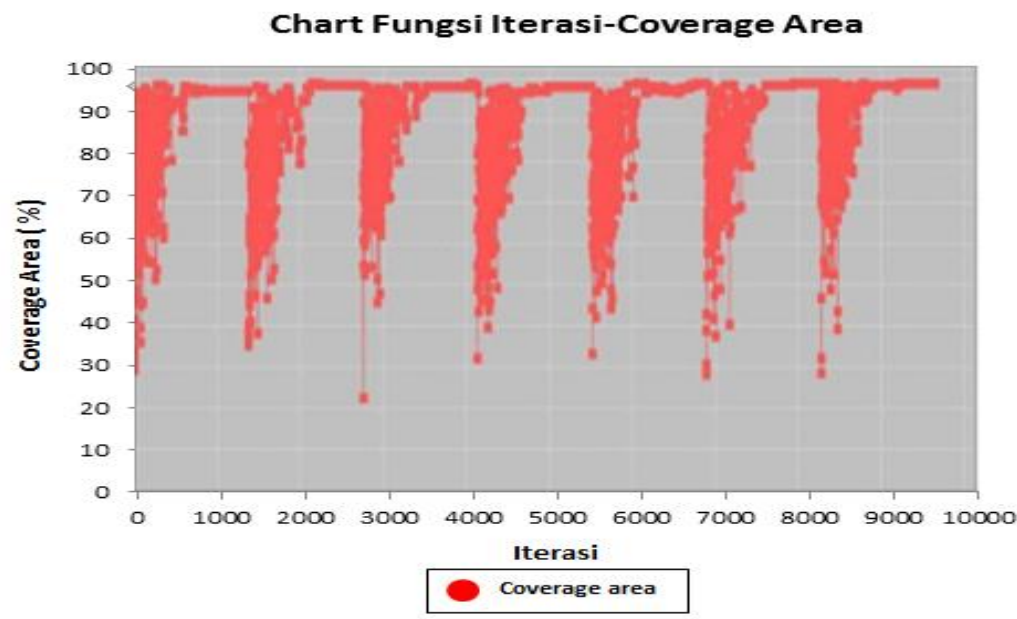

Gambar 4. Sample grafik Iterasi Koverage Area Hasil Pemodelan tinggi AP $120 \mathrm{~cm}$ propagasi LOS

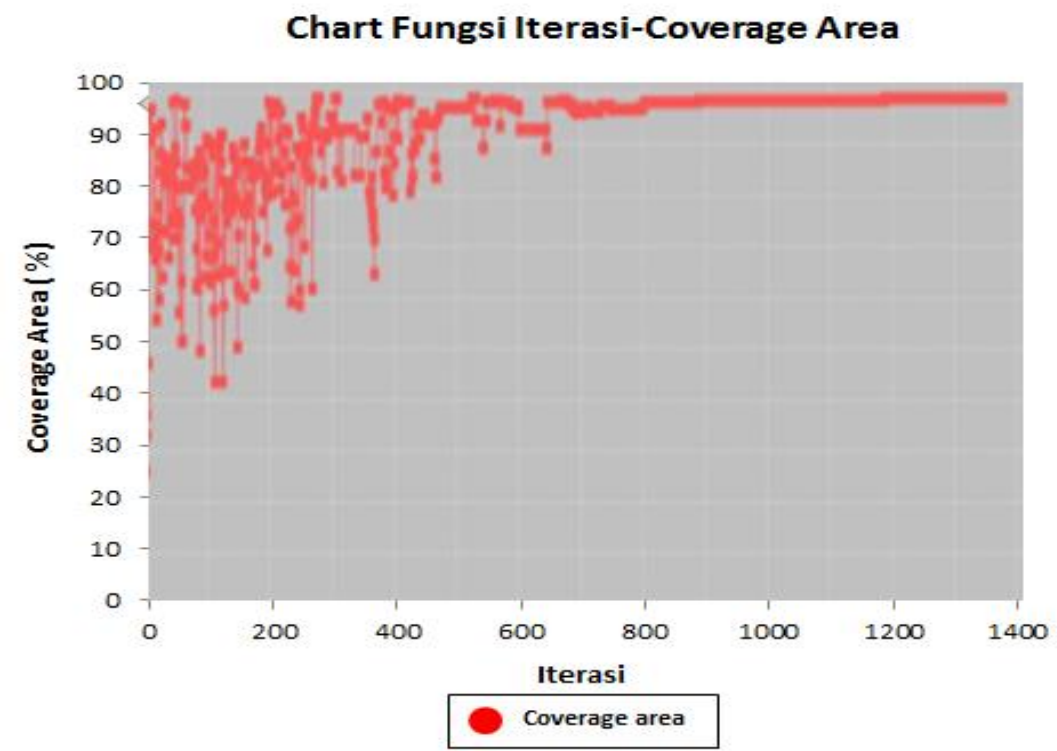

Gambar 5. Grafik Iterasi Koverage Area Hasil Pemodelan tinggi AP $230 \mathrm{~cm}$ dari propagasi LOS 


\section{HASIL DAN PEMBAHASAN}

Pada bagian ini akan dijelaskan mengenai serangkaian pengujian dan evaluasi terhadap metode yang digunakan. Pengujian dilakukan untuk mengetahui kinerja terhadap metode yang dihasilkan dari proses implementasi. Evaluasi dilakukan dengan cara menganalisis hasil pengujian tersebut, untuk kemudian dilakukan kesimpulan dan saran bagi perangkat lunak selanjutnya. Data yang digunakan dalam penelitian ini ada 648 data yang dikelompokkan berdasarkan koordinat access point dengan koordinat $(22,28)$ dan koordinat $(22,3)$ dan 3 (tiga) jenis ukuran tinggi access point yaitu $50 \mathrm{~cm}$, $12 \mathrm{~cm}$ dan 230 serta 2 (dua) jenis propagasi yaitu propagasi LOS (Line Of Sight) yang terdiri dari 43 data dan NLOS (Non Line Of Sight) yang terdiri dari 65 data.

Ada beberapa pengujian yang dilakukan dalam penelitian ini. Pertama-tama melakukan pengujian transmitter berdasarkan parameter merk, tinggi dan propagasinya terhadap receiver berdasarkan parameter koordinat, jarak, dan RSSI. Selanjutnya dengan membandingkan hasil pengujian berdasarkan parameter posisi access point sebenarnya dengan posisi access point hasil optimisasi menggunakan interferensi dengan metode simulated annealing. Akhinya dengan melakukan analisis data hasil optimisasi terhadap pengukuran awal.

\section{Penentuan Parameter Terhadap Transmitter.}

Pengujian yang dilakukan terhadap transmitter adalah dengan menentukan perangkat access point dengan Merk TP - Link, Tipe TL-WA701ND. Selanjutnya ,mengatur konfigurasi interferensi dengan menentukan merk perangkat dan nama access point. Menentukan parameter tinggi transmitter dan dikelompokkan menjadi 3 (tiga) jenis ketinggian yaitu ketinggian $50 \mathrm{~cm}, 120 \mathrm{~cm}$ dan $230 \mathrm{~cm}$ pada tahap sesudahnya.

Akhirnya dengan menentukan posisi awal transmitter pada koordinat $(22,28)$ serta menentukan jenis propagasi yaitu LOS (Line Of Sight) dan NLOS (Non Line Of Sight).Setelah mengatur konfigurasi perangkat access point, kemudian akan tampil data receiver yang merupakan data hasil pengukuran berdasarkan posisi access point sebenarnya.

Maka pada penentuan denah sebagai sampel penelitian, yaitu dengan memilih denah yang telah di package dalam bentuk file .PNG dengan resolusi gambar 420 x 816 pixel, serta melakukan optimisasi dengan Simulated annealing.

Pengujian yang dilakukan oleh peneliti dalam rangka optimisasi penempatan posisi access point menggunakan metode simulated annealing dilakukan sebanyak 3 (tiga) jenis sampel. Pengujian yaitu pada ketinggian access point $50 \mathrm{~cm}, 120 \mathrm{~cm}$ dan $230 \mathrm{~cm}$ dengan propagasi LOS dan NLOS.

\section{Hasil Simulasi dan Analisa}

\section{Analisa Pengaruh Perubahan Tinggi Access Point terhadap Nilai RSSI.}

Perubahan tinggi access point memberikan pengaruh yang besar terhadap nilai RSSI yang diterima oleh receiver. Dapat dilihat pada data hasil uji coba sebelumnya bahwa pada propagasi LOS, semakin tinggi access point yang terpasang, presentase koverage area yang dihasilkan lebih optimal. Sedangkan pada propagasi NLOS semakin tinggi access point yang terpasang presentase koverage area yang dihasilkan juga lebih optimal

\section{Analisa Kekuatan Hasil Optimisasi}

Setelah dilakukan ujicoba optimisasi menggunakan simulated annealing dengan membangkitkan secara acak koordinat kedua access point (random) sebanyak masing - masing 3 kali berdasarkan 3 (tiga) sampel ujicoba yaitu jenis ukuran ketinggian dan jenis propagasi.

Analisa data pada jenis ukuran ketinggian access point $50 \mathrm{~cm}$ dengan propagasi LOS, diperoleh persentase area terbaik sebesar $98.42 \%$ yaitu pada titik koordinat $(6,18)$ untuk access point pertama dan titik koordinat $(1,12)$ untuk access point kedua. Sedangkan pada jenis ukuran ketinggian access point $50 \mathrm{~cm}$ dengan propagasi NLOS, diperoleh persentase area terbaik sebesar $78.09 \%$ yaitu pada titik koordinat $(12,60)$ untuk access point pertama dan titik koordinat $(8,16)$ untuk access point kedua. Hasil ini seperti yang terlihat pada Gambar 3.

Pada jenis ukuran ketinggian access point $120 \mathrm{~cm}$ dengan propagasi LOS, diperoleh persentase area terbaik sebesar $98.66 \%$ yaitu pada titik koordinat $(7,13)$ untuk access point pertama dan titik koordinat $(35,5)$ untuk access point. Sedangkan pada jenis ukuran ketinggian access point $120 \mathrm{~cm}$ dengan propagasi NLOS, diperoleh persentase area terbaik sebesar $94.89 \%$ yaitu pada titik koordinat $(1,3)$ untuk access point pertama dan titik koordinat $(7,35)$ untuk access point kedua. Hal ini ditunjukkan pada Gambar 4. 
Pada jenis ukuran ketinggian access point $230 \mathrm{~cm}$ dengan propagasi LOS, diperoleh persentase area terbaik sebesar $98.66 \%$ yaitu pada titik koordinat $(1,16)$ untuk access point pertama dan titik koordinat $(16,8)$ untuk access point kedua dan alternative keduanya adalah titik koordinat $(1,1)$ untuk access point pertama dan titik koordinat $(20,6)$ untuk access point kedua. Sedangkan pada jenis ukuran ketinggian access point $230 \mathrm{~cm}$ dengan propagasi NLOS, diperoleh persentase area terbaik sebesar $97.83 \%$ yaitu pada titik koordinat $(29,20)$ untuk access point pertama dan titik koordinat $(1,19)$ untuk access point kedua. Hasil tentang Grafik Iterasi Koverage Area Hasil Pemodelan tinggi AP $230 \mathrm{~cm}$ propagasi LOS ini seperti yang ditunjukkan pada Gambar 5.

\section{Analisa Perbandingan Kekuatan Sinyal Hasil Optimisasi terhadap Kondisi Awal.}

Terjadi peningkatan kekuatan sinyal yang cukup signifikan terhadap penempatan posisi access point dengan kondisi awal dibandingkan hasil kekuatan sinyal setelah dibuat pemodelan menggunakan metode Simulated annealing.

Sebagai contoh pada kondisi awal ketinggian access point $120 \mathrm{~cm}$ dengan propagasi LOS memperoleh prosentase koverage area sebesar $11.51 \%$. Setelah dilakukan optimisasi menggunakan simulated prosentase koverage area sebesar $98.66 \%$. Dengan demikian kenaikan persentase koverage area sebesar $87.15 \%$.

Maka dengan hasil penelitian ini dapat juga dikatakan bahwa penempatan access point semakin tinggi dengan propagasi LOS yang akurat akan memperoleh prosentase koverage area yang lebih baik. Selanjutnya, optimasi dengan simulated annealing akan semakin meningkatkan kekuatan sinyal pada jaringan Wi-Fi.

\section{KESIMPULAN}

Penelitian yang merupakan studi kasus di Kampus Perbanas Institute Jakarta ini bertujuan untuk melakukan optimasi penempatan posisi Access Point pada jaringan WI-FI dengan menggunakan Metode Simulated Annealing. Penelitian ini menghasilkan suatu pemodelan penempatan titik akses dan kekuatan sinyal yang diperoleh secara optimal.

Hasil penelitian menunjukkan bahwa pada kondisi awal ketinggian access point $120 \mathrm{~cm}$ dengan propagasi LOS memperoleh prosentase koverage area sebesar $11.51 \%$. Selanjutnya, setelah dilakukan optimisasi menggunakan simulated annealing maka prosentase koverage area sebesar $98.66 \%$, dan kenaikan persentase koverage area sebesar $87.15 \%$.

Penelitian ini merekomendasikan bahwa semakin banyaknya pengujian yang dilakukan, maka akan mendapatkan kemungkinan hasil yang lebih baik terhadap hasil optimisasi sebelumnya. Ruang lingkup penelitian diperluas menjadi skala yang lebih besar untuk melihat kemampuan metode yang digunakan dalam penelitian.

\section{UCAPAN TERIMA KASIH}

Penulis mengucapkan banyak terima kasih kepada Direktorat Penelitian dan Pengabdian kepada Masyarakat (P3M) Perbanas Institute Jakarta atas bantuan pendanaan dalam pelaksanaan penelitian ini.

Akhirnya, penulis juga mengucapkan terima kasih kepada Dekan Fakultas Teknologi Informasi dan Ketua Program Studi Teknik Informatika Perbanas Institute-Jakarta yang telah mendukung terselesaikannya penelitian ini.

\section{REFERENSI}

[1] N.F Puspitasari, dan R.Pulungan, "Optimisasi Penempatan Posisi Access Point pada Jaringan Wi-Fi Menggunakan Metode Simulated Annealing", Citec Journal, Vol. 2, No. 1, pp. 51-64, 2015.

[2] A.Wanto, J.T. Hardinata, H.F Silaban, dan W.Saputra, "Analisis dan Pemodelan Posisi Access Point Pada Jaringan WI-FI menggunakan Metode Simulated Annealing", Jurnal Sains Komputer \& Informatika (JSAKTI), Volume (1) No. 1, pp. 134-143, 2017

[3] E.T, Procopio, A, de Assis Mota, L.T.M, Mota and L.R Barreto daSilva, Received Signal Stength Indication Modeling In Indoor Wireless Sensor Networks, American Journal of Applied Sciences 10 (9), pp. 10431049, 2013

[4] V. Aydın, İ.H, Çavdar, and Z. Hasırcı, Line of Sight $($ LoS $)$ Probability Prediction for Satellite and HAPs Communication in Trabzon, Turkey, International Journal ofApplied Mathematics, Electronics and Computers(IJAMEC), 4 (Special Issue), 155$160,2016$. 
[5] D. Henderson, S.H. Jacobson, and A.W. Johnson, The Theory and Practice Of Simulated-Annealing, https://www.researchgate.net/publication/225 260290 (Diakses pada 19 Januari 2019)

[6] I.P, Sari, T, Santoso., N.A, Siswandari, "Optimisasi Penataan Sistem Wi-Fi di PENSITS dengan Menggunakan Metode Monte Carlo, Seminar Proyek Akhir" Jurusan Telekomunikasi, Politeknik Elektronika Negeri Surabaya - ITS, Surabaya.pp 34-43, 2010

[7] K.P Kartika, T.B, Santoso, N.A, Siswandari, "Optimisasi Penataan Sistem Wi-Fi di PENS-ITS dengan Menggunakan Metode Algoritma Genetika", Seminar Proyek Akhir Jurusan Telekomunikasi, Politeknik Elektronika Negeri Surabaya - ITS, Surabaya, pp 13-23, 2010.
[8] S. Kouhbor, J. Ugon, J., A, Kruger., A Rubinov. Optimal Placement of AccessPoint in WLAN Basedon a New Algorithm, International Conferenceon Mobile Business, ICMB 2005, Sydney, Australia, 11-13 Juli 2005.

[9] S.D, Juniarto, "Optimasi Distribusi Barang Berdasarkan Rute Dan Daya Tampung Menggunakan Metode Simulated Annealing", Jurnal Teknik Informatika, PENS - ITS Surabaya.2011

[10] X, Zheng, G,Bao., R,Fu., and K, Pahlavan, The performance of Simulated Annealing Algorithms for Wi-Fi Localization using Google Indoor Map, Prosiding IEEE Vehicular Technology Conference, Quebec City, Canada, 3-6 September 2012. 